\title{
WORLD CONGRESS
}

The Participants in the Second World Congress of Anaesthesiologists have dispersed to the four corners of the glote, each to his daily round of service in the practice of anaesthesia. Each and cvery one of these must at some time reflect on the Congress and its meaning for him. For some, the great experience ma! have been the opportunity to visit a new continent, a new country, a new people. Others may have had the satisfaction of meeting "great names". in the specialty, and the pleasure of finding that these names belonged to kindls and unassuming human beings. For the traveller of yesterday there was the opportunity once again to renew old friendships, and to make new friends.

Transcending all other experiences of the Congress, however, was the sharing of knowledge through the presentation and thoughtful discussion, by experts from many lands, of the scientific basis and clinical applications of anaesthesia. No number of printed words can ever cqual in value even a few brief hours of such discussion: In such an exchange undoubtedly the seeds have been sown for much future progress in anaesthesia, to the ultimate benefit of mankind.

We venture to predict that the lasting monument to the World Congresses of Anaesthesiologists, both past and future, will be increased knowledge and mutual understanding and respect amongst the anaesthetists of our world, and better anaesthesia for all the people of the world.

\section{"NEW ERA"}

With the publication of this issue, the Journal enters a new stage of 'development. The current volume will be published in six issues, appearing bi-monthly. It is the hope of the Editorial Board that the new policy of more frequent publication will reduce the delay between receipt of communications and their appearance in print-a factor which has in the past proved frustrating both for contributors and for the Editor. 


\section{CONGRES MONDIAL}

LES CoNfrìres qui ont assisté au Deuxième Congrès mondial des Anesthésiologistes sont maintenant dispersés aux quatre coins du monde, chacun étant occupé à la besogne quotidiennie de son service et pratiquant l'anesthésie. Tous et chacun d'eux, à l'occasion, doivent se rappeler ce Congrès et son importance pour chacun. Pour les uns, il est possible que la plus grande expérience ait été l'opportunité de visiter un nouveau continent, un:nouveau pays, un nouveau peuple. Pour d'autres, le plus grand plaisir, au cours du congrès, peut avoir consisté en la rencontré de "grands personnages" de la spécialité et en la découverte que ces individus sont des humains pleins de bonté et sans prétention. Pour le voyageur d'hier, c'était une nouvelle opportunité de renouer d'anciennes amitiés et de se faire de nouveaux amis.

Cependant, au-dessus de toutes les autres expériences du Congrès, il y avait le partage des connaissances scientifiques par la présentation et la discussion judicieuse, par des experts de plusieurs pays, des bases scientifiques et des applications cliniques de l'anesthésie. Un nombre illimité de termes imprimés ne peuvent pas avoir la valeur de quelques brèves heures. de semblable discussion. Avec de tels échanges, il n'y a pas de doute que des grains de semencế ont été mis en terre pour donner naissancé à de grands prisogrès futurs en anesthésie pour le bienfait ultime du genre humain.

Nous osons prédire que ce qui survivra du congrès mondial des anesthésiologistes, aussi bien du passé que de celui à venir, ce sera une connaissance accrue et une entente et un respect mutuels entre les anesthésistes de notre mondepuis une meilleure anesthésie pour tous les gens du monde.

\section{"ERE NOUVELLE"}

Avec la publication de ce numéro, le journal entre dans une nouvelle phase de développement. Le volume actuel va être publié en six numéros, ùn apparaissant à tous les deux mois. Les éditeurs nourrissent l'espoir que cet te nouvelle initiative de publier plus souvęnt réduira le délai entre la réception des communiqués et leur publication; ce fait, dans le passé, s'est avéré gênant aussi. bien pour les auteurs que pour les éditeurs. 